\title{
我が教室に於ける先天股脱骨切り術の成績検討
}

$\begin{array}{lllll}\text { 鹿児島大学医学部整形外科 } & \text { 荒 } & \text { 木 } & \text { 崇 } & \text { 交 } \\ & \text { 久 } & \text { 保 } \text { 田 } & \text { 不 } & \text { 志 } \\ & \text { 松 } & \text { 元 } & \text { 四 } & \text { 郎 } \\ & \text { 東 } & & \text { 成 } & \text { 照 } \\ & \text { 有 } & \text { 馬 } & \text { 純 } & \text { 郎 }\end{array}$

\section{The Results of Osteotomies for Irreducible Congenital Dislocations of the Hip Joint in Our Clinic}

By

\author{
T. Araki, J. Kubota, S. Matumoto, \\ N. Higashi and J. Arima \\ Department of Orthopaedic Surgery, Kagoshima University. \\ (Direct.: Prof. A. Miyazaki)
}

我が教室に於ても整復不可能な先天股脱に対しては 姑息的な手段である骨切り術の方法を取つています。 昭和 29 年より 31 年に至る 3 年間の陳旧性先天股脱 は 42 例であり，11才より 15 才迄が最も多く 14 例, 次が6才より10才迄で10例であり，他は少くこの時 期を切骨術の適応としています。最近早期治療の効果 が漸次表われて来てはいるが, 当地では依然として陳 旧性先天股脱を多数経験する現状である。我々の外来 を来訪した時の主訴内容別を検査するに跛行が最も多 <21 例, 次が疼痛 10 例, 以下開排制限, 疲労の順で 雑音を主訴にした 2 例の患者もあつた。

昭和 26 年以前の「カルテ」は戦災或は火事のため 不満足であつたため昭和 27 年 以降を主に対象として 検査した。直接検診 10 例， 11 関節，間接検診 5 例, 6 関節計 15 例， 17 関節に就き調査したのでその成績 に付き検討を加へて見たいと思う。手術時年柃は最少 8 才, 最高 27 寸の間に行はれ 13 おが最も多い。通 信或は直接検診で術後疼痛, 跛行の有無, 步行距噍の 増大を検査し疼痛消失した者 3 例, 堌悪した者 7 例む あり, 軽央，不変 5 例であつた。跛行は正常歩行なく 軽快 6 例で不変 4 例, 増悪 3 例であつた。步行距離は 不変が 6 例で最も多く正常 2 例, 術後堌大 3 例, 術前 より紫けなくなつた者 3 例あり成績は良好ではない。 更に疼痛部位別を見るに患肢大転子部が最も多く6 例, 次は大眼骨外側から内側へかけて疼痛あり, 鼠蹊 部各々 4 例であつた。症例を举げるに 10 才女，両先
天股脱。術前 $8 \mathrm{~km}$ 歩行すると軽度腰脤あるのみであ つた。近位転子下角状骨切り術をなし 1 年 10 ケ月の 現在 $2 \mathrm{~km}$ 歩行すると大転子部より大眼骨内側へ疼痛 疲労を訴兄る。14 才女, 左先天股脱。術前 5 分位し か歩行出来なかつたのが転子下角状骨切り術をなした 11ケ月後子尚依然として疼痛あり殊に鼠蹊部に甚しく $100 \mathrm{~m}$ 位しか歩行出来ない。良好な症例として 17 才， 女, 右先天股脱 9 年前転子下骨切り術をなし現在日常 生活で全く疼痛消失し $5 \mathrm{~km}$ 歩いて軽度疲労, 大転子 部に疼痛があると云つているこのよ5に良い例るある が，切骨術をなし疼痛増悪は如何にして起るものであ ろ5か。切骨部位或は手術術式にも関係あるが矢張り 術後の筋平衡が急に変化したためと思はれ，尚今後経 過を追つて色々追求して見たいと考えている。

次に直接検診例で種々検討して見ると手術術式は 2 転子間角状骨切り術をなし，他の 8 例は全部転子下角 状骨㽘り術である。疼痛，跛行，Trendelenburg 症 候術後増大を $(+)$, 軽快或は消失を $(-)$, 不変を $( \pm)$ で表はすと「ト」氏症候堌悪は 2 例, 不変 6 例, 陰性 2 例であつた。外転筋力はぜんまい秤で健側と比較し 患側は平均 $1.5 \mathrm{~kg}$ 弱いるのが多かつた。見脚上の外開 角は増加したものが多い。

判定としては色々の方法があるが我々はごく簡単に 3 段階に分類した。即ち疼痛，跛行全くなくなり運動 正常の者を優とし，疼痛，跛行，「卜」氏症候いずれ かある者を良とし共に増悪した者を可とすれば優は僅 
かに 2 例であり, 良 7 例, 可 1 例となつた。優の判定 を下した症例を举げると 13 于男, 右先天股脱。転子 下角状骨切り術をなし 2 年後, 疼痛, 跛行全く消失,

「ト」民症候陰性, 運動制限なく他の生徒と同じ生活 をなしている現状である。レ線的に囦蓋下縁で切骨が 行はれ起立位で小転子に体重がかかつている。骨頭に は何等変化がない。次の症例は 13 才女, 左先天股脱, 良の判定をした者であるが疼痛, 跛行の主訴の下に脱 曰位田蓋成形術を施行した。2 年後跛行は術前と較べ 良好となつたが疼痛は依然として取れずレ線的に骨頭 核は漸次破壊され骨端線消失, 新臼蓋に骨硬化像を見 る。転子間角状骨切り術を更になし 1 年後矢張り疼痛 を訴兄跛行は軽快したがレ線的に骨馶は殆んど消失し たよ5に見える。かかる骨変化は脱臼位臼蓋成形術の ため骨頭に更に荷重が加はつたものと思5。27才女, 両先天股脱。両側転子下角状骨切り術をなした。術後 4 年, 跛行は大部良好となつたが疼痛ありレ線的に骨 頭の著明な变形を見る。

以上症例を説明したが，年龄的には 8 才と 13 才が 最もよい成績を得て居り先人が 既に 発表している如 く 10 才未満が良好と思万。前方凸, 後方凸子検討し たが前回高岸氏が報告した如く大して成績に差はなか つた。先天股脱に対する骨切り術は疼痛の面から云兄 ばあまり良好な成漬ではなく術後疼痛は堌強するもの

\begin{tabular}{|c|c|}
\hline 年 令 & 例 数 \\
\hline $0 \sim 5$ & 1 \\
\hline $6 \sim 10$ & 10 \\
\hline $11 \sim 15$ & 14 \\
\hline $16 \sim 20$ & 8 \\
\hline $21 \sim 25$ & 6 \\
\hline $26 \sim 30$ & 3 \\
\hline 30 以上 & 0 \\
\hline 計 & 42 \\
\hline
\end{tabular}
主瓶內菑別

\begin{tabular}{|cc|c|}
\hline 主 & 訴 & 例 数 \\
\hline 疼 & 痛 & 10 \\
\hline 疲 & 労 & 2 \\
\hline 跛 & 行 & 21 \\
\hline 開排制限 & 7 \\
\hline 雑 & 晋 & 2 \\
\hline 計 & 42 \\
\hline
\end{tabular}

患肢疼痛部 位

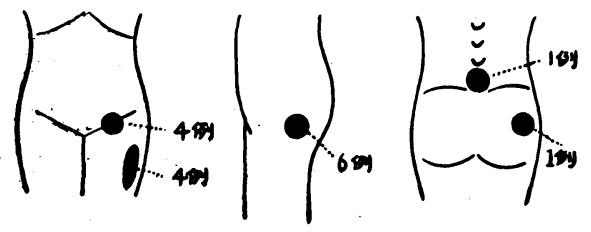

が多く今後尚研究しなければならぬと感ずる次第であ る。レ線上は起立位で小転子下が蓋下縁にあるのが 最もよい。

\begin{tabular}{|c|c|c|c|c|c|c|}
\hline 氏 名 & 年令 & $\begin{array}{l}\text { 逢後 } \\
\text { 年月 }\end{array}$ & 術式 & 疼痛 & 跛行 & 卜症候 \\
\hline Y.H & 14 & 0.11 & A & + & - & + \\
\hline E. T & 14 & 1. 3 & B & \pm & \pm & \pm \\
\hline N. I & 10 & 1.10 & B & + & + & + \\
\hline K.M & 15 & 0.6 & B & 不明 & 不明 & \pm \\
\hline K. Y & 18 & 1. 4 & B & - & + & \pm \\
\hline K. I & 13 & 1. 0 & B & - & \pm & - \\
\hline Y. I & 27 & $\begin{array}{l}\text { 3. } 6 \\
\text { 2. } 5\end{array}$ & B & + & \pm & \pm \\
\hline Z. 0 & 13 & 1. 3 & A & + & - & \pm \\
\hline T.H & 13 & 5. 9 & B & + & \pm & \pm \\
\hline T.Y & 8 & 9. 0 & B & - & - & - \\
\hline
\end{tabular}

\begin{tabular}{|c|c|c|c|c|c|c|}
\hline \multirow{2}{*}{ 氏 名 } & \multirow{2}{*}{$\begin{array}{l}\text { 開排 } \\
\text { 制限 }\end{array}$} & \multicolumn{2}{|c|}{ 外轉筋力 } & \multirow{2}{*}{ 正坐 } & \multirow{2}{*}{$\begin{array}{c}\text { 外開何 } \\
\text { 增減 }\end{array}$} & \multirow{2}{*}{ 判定 } \\
\hline & & 健側 & 患側 & & & \\
\hline Y.H & - & 4.0 & 2.0 & + & + & 良 \\
\hline E. T & \pm & 2.7 & 1.2 & + & + & 证 \\
\hline N. I & + & 不明 & 不明 & - & - & 可 \\
\hline K.M & - & 3.8 & 2.7 & - & - & 良 \\
\hline K. Y & - & 5.0 & 4.0 & + & + & 食 \\
\hline K. I & - & 5.1 & 4.5 & + & \pm & 傮 \\
\hline Y. I & - & 5.0 & 4.3 & + & - & 良 \\
\hline Z. 0 & - & 7.0 & 5.5 & + & \pm & 良 \\
\hline $\mathrm{T} . \mathrm{H}$ & + & 4.5 & 3.5 & + & - & 良 \\
\hline T.Y & - & 5.5 & 5.0 & + & + & 優 \\
\hline
\end{tabular}

\section{兵問}

\section{飯塚病院整形 松田 正 次}

先股脱の角度の决定は筋力ともにらみ合せ慎重を要 する。不可であつた例は少し角度が不足であつたので はないかと思われる。

\section{梊問}

\section{飭 大 玉 井 教 授}

「疼痛が主訴であるすのの中で骨切術をして疼痛のと れたものは何例あるか?」 
「跛行等が主訴であるもので骨切術をしたもので疼痛 があらはれたものが何例あるか?」

兵問

長㥓労災病院 難 波 雄 哉

両側に骨切り術を行つていられる様ですが。 両側に骨切り術を行つたのは何例でありますか。 両側骨切り術の成䟺についてらかがいます。

追 加

鹿大宮 崎 教 授

年長者（児）の所謂非観血的整復の不可能のものに 対し, 転子下骨切り術の在り方については, 結局, 脱 臼度の高いるの, 骨関節炎の症候をレ線的に認められ るものは, 悪い結果を来す事が多いこととなつた。然 し乍ら中には非常に良い成績を示すものもあつて, 術
後に牽引療法その他について, 筇, 腱附着物等に過度 の負担の及ばない様にすれば, 或る程度の効果を期待 出来るのではないかと考党るが，本日発表した限りに おいては，好ましくない結果を示した。

\section{追加 買問}

\section{長㥓大学 永 井 教 授}

(1) 唯今の成績の中に正坐不能が 2 例ありましたが これは手術時感染か何かですか。

答 Kontraktur による。

(2) 従来骨切り術は術前の関節の譏能の良いるのに 対して, 術後他の観血的整復術等と異つて関節の譏能 障害を来さないと云う概念であつたが, Kontraktur により関節機能障碍を残すとすれば相当に注意しなけ ればならない。

\section{股関節の Jergesen-Abbott 展開法に就て}

$\begin{array}{ccccc}\text { 九州厚生年金病院整形外科 } & \text { 内 } & \text { 村 } & \text { 正 } & \text { 雄 } \\ & \text { 浅 } & \text { 野 } & \text { 昌 } & \text { 男 } \\ & \text { 太 } & \text { 田 } & \text { 明 } & \text { 二 }\end{array}$

On the Jergesen-Abbott's Exposure of the Hip Joint

By

M. Uchimura, M. Asano and M, Ota

Kyushu Welfare Pension Hospital

股関節の展開法に就いては, 古来多数の報告があり 我々の乏しい文献によつても30 以上の人名が付され た皮膚切開法を集め得た。この中には単一又は特殊の 目的のために用いられる展開法と, 関節内の構造を視 野に置く展開法とが含まれており，この 2 者は別に考 えるべきであろう。前者に含まれるものには，例えば 化膿性炎症の関節高切開に用いる、V.Langerbeck法, Lange-Payr 法, 外傷性後方脱臼に際しての観血的整 復術に用いられる Ober 法, Dollinger 法, Osborne 法, 䯏臼蓋成形術に用いられる Lange 法, Brittainが 彼の Ischiopemoral Arthrodesis に紹介した法等が ある。又この Brittain に似たもので古典的の Kocher 法がある。
関節の構造を直視下におく必要のある場合の展開法 は略々

1. 前方展開法

2 . 前側方展開法

3. 側方展開法

4. 後方展開法

5.内方展開法

に分けられる。

\section{1. 前方展開法}

Deutschländer 切開は腸骨稜に付着する暂筋を剝 離し更に大腿筋膜張筋, 縫工筋, 大腿直筋の起始部を 横切して侵入するのであるが, 最近は大眼筋膜張筋を 一時的に切離する Luck 切開や, 大卧直筋のみを横 